1989

\title{
Experimental Test of Some Notions of The Fact/ Opinion Distinction in Libel
}

Jeremy Cohen

Diana Mutz

University of Pennsylvania, mutz@upenn.edu

Clifford Nass

Laurie Mason

Follow this and additional works at: https://repository.upenn.edu/asc_papers

Part of the Communication Commons

\section{Recommended Citation}

Cohen, J., Mutz, D., Nass, C., \& Mason, L. (1989). Experimental Test of Some Notions of The Fact/ Opinion Distinction in Libel. Journalism and Mass Communication Quarterly, 66 11-17, 247. Retrieved from https://repository.upenn.edu/asc_papers/636

Note:

At the time of this publication, Diana Mutz (now a faculty member at the Annenberg School for Communication University of Pennsylavania), was a faculty member in the School of Journalism and Mass Communication at Wisconsin-Madison.

This paper is posted at ScholarlyCommons. https://repository.upenn.edu/asc_papers/636

For more information, please contact repository@pobox.upenn.edu. 


\title{
Experimental Test of Some Notions of The Fact/ Opinion Distinction in Libel
}

\author{
Disciplines \\ Communication | Social and Behavioral Sciences
}

Comments

Note:

At the time of this publication, Diana Mutz (now a faculty member at the Annenberg School for

Communication University of Pennsylavania), was a faculty member in the School of Journalism and Mass Communication at Wisconsin-Madison. 


\section{Experimental Test of Some Notions of The Fact/ Opinion Distinction in Libel}

Jeremy Cohen, Diana Mutz, Clifford Nass and Laurie Mason

Opinion caused more harm to reputation than fact in this experiment.

Courts must decide under the rules of American libel law whether a defamatory statement is a statement of opinion or of fact. Implicit in the law are assumptions about the manner in which readers distinguish between fact and opinion, a fact that suggests value in exploring the criteria people use to make such distinctions.

American law actually distinguishes among three types of defamatory statements. Statements of fact that are true receive nearly absolute protection. ${ }^{1}$ Statements of fact that are false subject the author to liability, although numerous defenses based on the author's conduct and the content of the message are available that may mitigate or eviscerate such liability. ${ }^{2}$ Statements of opinion, no matter how vitriolic in nature, are protected from libel suits. ${ }^{3}$

\section{Opinion}

After nearly two centuries of varying levels of state by state common law protection, the Supreme Court found a First Amendment recognition of the fact/opinion distinction in 1974 when Justice Powell held in Gertz v. Welch that,

Under the First Amendment, there is no such thing as a false idea. However pernicious an opinion may seem, we depend for its correction not on the conscience of judges and juries but on the competition of other ideas. But there is no constitution.al value in false statements of fact. ${ }^{4}$

Since Gertz, the arena of safe opinion has encompassed all topics, not just the political speech protected in most common law. The legal theory underlying the Gertz dicta on opinion is that only statements that can be proved or disproved may be considered defamatory and therefore subject to redress for harm to reputation.

A recurring problem has been the difficulty or developing a suitable legal distinction that can be applied consistently. In the end, statements accepted by one reader as opinion may be interpreted by another as fact. A suit against columnist Ellen Goodman provides a useful example. In 1983, Goodman wrote a column highly critical of the outcome of a rape trial that found the defendants not guilty on the rape charge, yet guilty of a charge of malicious damage to an automobile involved in the incident. Goodman wrote,

What is agreed upon by everyone is that the men took turns. While one was jumping on her, the others were jumping on the car. At the end, the bruised auto was rolled over the embankment. The bruised woman was left naked in the January night .... On June 17 , they were found innocent of damaging the woman but-hosanna and pass the scales of justice-guilty of damaging the car. ${ }^{5}$ 
In the ensuing libel suit against Goodman, the plaintiffs argued that the statement, "while one was jumping on her, the others were jumping on the car," was a false statement of fact. The judge found the column to be opinion containing no statement of fact. The judge based his decision on the reasoning that Goodman,

uses the rhetorical device or personification to make an automobile a person and by adroit cadence of parallel sentences compares the favorable treatment of a motor vehicle to the shabby treatment of women in rape cases. ${ }^{6}$

It is easy to see how some might have seen Goodman's comments as verifiable statements of factespecially readers not adroit enough to recognize parallel constructions used as literary device. Decisions such as this one call into question the tenet that law must be applied consistently and subject the judge to the charge that his decision was based on visceral (if literary) reaction, rather than predictable legal rules.

Further complicating the issue, the Supreme Court did not provide in Gertz a systematic means for either federal or state courts to distinguish between fact and opinion statements. The problem was left to future cases and at this writing, the High Court has accepted no appeal for hearing that would provide a conclusive answer at the national level. Nonetheless, a federal Court of Appeals developed a four-part test in 1984 that has received wide attention. The case considered a libel suit against nationally syndicated columnists Evans and Novak by a political science professor who had been the subject of their column. Evans and Novak questioned the professor's leftist views in their column and argued in court that the column was opinion and therefore entitled to First Amendment protection. Writing for a plurality in Oliman v. Evans, Judge Starr set four criteria to distinguish fact from opinion.

1)What is the common usage or meaning of the allegedly defamatory statements? ${ }^{7}$

2)To what degree are the statements at issue verifiable as statements of fact? ${ }^{8}$

3)What is the micro-context of the statements-that is, what is the tone of the rest of the article or story? ${ }^{9}$

4)What is the macro-context-that is, do the statements appear on a news or editorial page or in a forum regularly recognized as one encouraging opinion $?^{10}$

Of special relevance to this study is criterion 4, the macro-context of the statement. Starr found it very important that the statements in question appeared in a column and that the column appeared on the op/ed page, "the well-recognized home of opinion and comment."11 Page environment, then, is assumed to be a primary indicator for readers of whether a statement is fact or opinion.

In a dissenting opinion, however, Judge Wald was less impressed than Starr by the macro-context in which the statements occurred, writing that "the immediate context in which the statement was made does little to warn a reader to regard with skepticism what might otherwise appear to be an assertion of fact." ${ }^{12}$ As legal commentator Timothy Gleason has pointed out, "Judge Starr's characterization of the context as one in which readers will expect opinion statements is no less credible than Judge Wald's assertion that the context supports a finding of fact." ${ }^{13}$ 
Another aspect of macro-context that could assume relevance in fact/opinion deliberations is whether the article has a by-line. Although this potential indication has never been addressed by the courts, a 1985 study commissioned by the American Society of Newspaper Editors (ASNE) found evidence that readers tend to equate a by-line with opinion. ${ }^{14}$ The correlation, explored in more detail below, justifies an intitial examination of the possibility under experimental conditions.

In the process, then, of protecting opinion from libel suits, the courts imbed two implicit assumptions. ${ }^{15}$ First, the courts assume that individuals, whether readers of a newspaper, viewers of television, or other consumers of information, distinguish between fact and opinion in the messages they receive through the mass media. Second, the courts must assume that judicial formulas accurately distinguish between fact and opinion.

With libel suits regularly involving seven figure damage claims, ${ }^{16}$ these two assumptions become important to journalists, publishers, attorneys, judges and the subjects of journalistic scrutiny who sometimes turn to the courts to vindicate possibly tarnished reputations. ${ }^{17} \mathrm{~A}$ first step toward testing these assumptions is to empirically determine whether and how people perceive differences between defamatory opinion and factual statements and the effects of these perceptions. Empirical attempts to date, however, have been limited in scope and none are applicable directly to specific fact/opinion formulas developed by the courts. ${ }^{18}$

This paper presents experimental tests of some assumptions about the ways in which readers distinguish fact from opinion in a defamatory context, and about differences in impact on readers based upon their perceptions of whether a report is fact or opinion.

We first discuss and test two aspects of the macro-context of an article that might effect a reader's perceptions of fact/opinion: page environment and by-line.

We then empirically examine the differential effect of perception of fact versus opinion on reader assessment of the defamed person. The constitutional distinction between fact and opinion is based not on the question of whether fact is capable of causing more damage to reputation than opinion, but simply on the Gertz rationale that a fact can be proven true or false while an opinion can be neither right nor wrong. ${ }^{19}$ Nonetheless, the fact/opinion distinction seems to carry at least an implicit assumption that people recognize differences between fact and opinion and weigh those differences accordingly.

Page Environment. Courts have developed numerous approaches to making distinctions between defamatory statements that are opinion and those that are presented as fact. Page environment is used as a criterion in many of these judicial fact/opinion tests. Page environment refers to the characteristics of the page on which a newspaper article appears. Is the material on a news page normally associated with factual stories, or on a page set aside for editorials, letters to the editor, and opinion columns?

A basic approach that relics on page environment as a threshold element appeared in Ollman v. Evans. ${ }^{20}$ The four federal Courts of Appeal fact/opinion libel cases decided since then have incorporated the Ollman guidelines, a strong indicator of an emerging coalescence of approach. ${ }^{21}$

In focusing on the issue of whether the defamatory statements in question appeared on a news page or on an opinion/editorial page of a newspaper, the judicial assumption is (1) that readers are aware they are reading statements placed either on a news page or on an op/ed page; and (2) that readers are aware of the difference in function and content of news and op/ed pages; and (3) that these 
recognitions play a significant role in reader perception of whether defamatory statements are fact or opinion.

Contradictory Findings. There are reasons to doubt these assumptions. One-fourth of those polled in the ASNE survey believed that "columnists are not entitled to include opinions in their columns." ${ }^{22}$ About half those polled believed the editorial pages contained about the same amount of opinion as the rest of the newspapers. ${ }^{23}$ About one-fourth believed the front page actually contains more opinion than the rest of the newspaper. ${ }^{24}$ The study also found that $40 \%$ of readers believe "most media don't do a very good job of separating fact from opinion." 25

A similar study, commissioned by the Associated Press Managing Editors Association, found that one in four readers believe newspapers "mix fact and opinion." 26

It is easy to conclude from these findings that the appearance of statements on an op/ed page or a news page is not a reliable indicator of reader perception. At the least they suggest continued attention to the ways in which people distinguish between fact and opinion.

Byline. Although the courts have not considered by-line as a reliable fact/opinion indicator, 4 of 10 readers polled by ASNE believed "When a reporter's byline is put on a story, the reporter is entitled to put his or her opinions in the story," 27 Implicit in the finding that a significant minority or readers appear to misunderstand the meaning or purpose of a by-line is the possibility that readers who equate byline with the presence of opinion would incorrectly identify bylined stories, no matter where they appeared, as more opinionated than comparable stories that did not have a byline.

Methods. Fifty-seven Stanford students in a class on communication law ${ }^{28}$ read a mock two-page newspaper comprising a front page and an editorial page. Each page had two articles, one with a byline and one without a byline. Thus, environment, byline and their interaction constituted the manipulations in the experiment.

To control for individual differences, we created four forms of the mock newspaper. Each form of the newspaper contained the same four articles, with each article chosen to be a) critical of a single (pseudonymous) individual and $b$ ) at issue in a libel case decided on the basis of the fact/opinion distinction. ${ }^{29}$ The design of the study is a two-by-two Latin square, with each article appearing with a different combination of environment and by-line for each of the four forms of the newspaper. ${ }^{30}$

The first dependent variable of interest is the extent to which the subjects perceived each article to be fact or opinion. Subjects were asked to underline the phrases in each article that they felt were statements of opinion rather than statements of fact, whether true or false. We then totaled the number of underlined phrases for each article. Later in the experiment, subjects were asked to rate the fact/opinion nature of each article as a whole on a 19-point continuous scale ranging from "Mostly Opinion" to "Mostly Fact."

Opinion change is the second issue addressed in our study. We wanted to know which carried greater potential for damage to reputation, messages perceived as defamatory facts or those perceived by readers as opinion?

For each of the four persons named in the articles, students were asked to respond to the question, "How would you rate your impression of Anthony Collins [i.e., the defamed person)? Would you say that 
your impression of him is:". The question utilized a 19-point continuous scale ranging from "Positive" to "Negative." The use of fictitious names in the articles ensured that the subjects did not have strong pre-existing attitudes toward the people to be evaluated.

\section{Results}

The two measures of fact/opinion - the total number of underlined phrases and the subject's overall evaluation-showed a low magnitude of correlation ( $r=.29 ; p<.001)$, so separate analyses were run for each of the two measures of the dependent variable. Table 1 presents means, by article and treatment condition, for the number of opinion statements (underlined phrases). Table 2 presents corresponding means for the fact-opinion scale. For page environment, seven of the eight comparisons of the means are as predicted, with the eighth showing virtually no difference. The byline/no byline condition shows no systematic patterns.

TABLE 1

Mean scores for Number of Opinion Statements per Article by Condition

$\begin{array}{lclll} & \text { Front } & \text { Editorial } & & \\ & \text { Page } & \text { Page } & \text { Byline } & \text { No Byline } \\ \text { Dr. Drill 'n Fill 'n Bill } & 12.1 & 15.8 & 13.1 & 15.1 \\ \text { New York Tallest Building } & 14.9 & 18.0 & 17.6 & 15.0 \\ \text { Marxist Prof's Intent } & 20.8 & 20.7 & 20.6 & 20.9 \\ \text { A Giggle of Guts } & 9.52 & 10.7 & 10.7 & 9.45\end{array}$

Cell Ns vary from 26 to 31

TABLE2

Mean Scores for Fact/Opinion Nature of the Article.

$\begin{array}{lcccc} & \begin{array}{c}\text { Front } \\ \text { Page }\end{array} & \begin{array}{c}\text { Editorial } \\ \text { Page }\end{array} & \text { Byline } & \text { No Byline } \\ \text { Dr. Drill 'n Fill 'n Bill } & 6.9 & 5.9 & 6.3 & 6.4 \\ \text { New York Tallest Building } & 5.5 & 4.6 & 4.7 & 5.5 \\ \text { Marxist Prof's Intent } & 5.6 & 4.8 & 5.4 & 5.1 \\ \text { A Giggle of Guts } & 6.6 & 5.9 & 6.7 & \\ \text { Cell Ns vary from 26 to 31. } & & & \end{array}$

The first step in analyzing the Latin Square design was to control for individual differences and to check for possible confounding effects of the four versions of the mock newspaper. As expected, there were significant individual differences for both total number of opinion phrases in each article $(p<.001)$ and overall evaluations of the articles $(p<.01)$. Fortunately, there was no significant effect for the version of 
the newspaper for either measure ( $p>.1$ and $p>.6$, respectively), indicating that the articles could be viewed as replications of one another as intended in the original design.

Analyses of variance were done for the relationship between page environment and by-line and the total number of underlined phrases. There is a highly significant difference $(F(1,53)=14.0 ; p<.001))^{31}$, with articles on the front page seen as having fewer opinion statements than articles on the opinion page (Mean $=14.2$ vs. 16.4). There is no effect, however, for byline $(F(1,53)=.16 ; p>.5)$, nor is there a significant interaction effect $(F(1,53)=.03 ; p>.5)$.

The results for overall evaluation of the article show a similar pattern. Articles on the front page are seen as containing significantly less opinion than articles on the opinion page (Mean=6.1 vs. $5.3 ; F(1,53$ ) $=5.5 ; p<.05)$. Again, there is no effect for byline $(F(1,53)=.08 ; p>.5)$ and the interaction term is not significant $(F(1,53)=.00 ; p>.3)$. The environment of an article does tend to influence readers' perception of how opinionated the article is. Byline, however, does not seem to have an effect on the reader's perception of opinion.

Turning to the second assumption implicit in fact/ opinion issues in libel, we examine the relationship between the perception of the extent of opinion in a defamatory article and the reader's evaluation of the defamed person to see if perceived factual assertions are truly more damaging than perceived statements of opinion. We also test for any effect on damage to reputation for page environment and by-line, independent of their effect on the reader's evaluation of fact/ opinion. To test these relationships, evaluation of the article's referent is the dependent variable in an analysis of covariance model with either total number of opinion statements or overall assessment of how much opinion the article contained as a covariate and either page environment or by-line as the independent variable. ${ }^{32}$ The results are presented in Table 3.

TABLE 3

F-Statistics for Effects on Evaluations of Defamed Person

$\begin{array}{llccc}\text { Covariate } & \text { Covariate F } & \text { Indep. Effect F } & \text { Interaction F } \\ \text { Number of Phrases } & \text { Environmental } & 16^{* *} & 2.1 & 1.1 \\ & & (1,53) & (1,53) & (1,47) \\ \text { Number of Phrases } & \text { Byline } & 17^{* *} & 1.1 & 1.2 \\ & & (1,53) & (1,53) & (1,47) \\ \text { Overall Eval. } & \text { Environment } & 4.1^{*} & 3.8 & 1.7 \\ & & (1,53) & (1,53) & (1,47) \\ \text { Overall Eval. } & \text { Byline } & 3.8 & 1.3 & .04 \\ & & (1,53) & (1,53) & (1,47)\end{array}$

When the total number of opinion statements is used as the measure of how much opinion exists in an article, opinion is significantly related to the perception of the referent, in models that include either page environment $(F(1,53)=16 ; p<.01)$ or by-line $(F(1,53)=17 ; p<.01)$. Surprisingly, the direction of the relationship is negative; that is, readers who see an article as mostly opinion think less of the referent than readers who see the article as mostly fact $(r=.23 ; p<.001)$. Neither environment $(F(1,53)$ 
$=2.1 ; p>.4)$ nor byline $(F(1,53)=1.1 ; p>.5)$ nor the interaction of environment or by-line with number of opinion phrases is significant.

The results using overall evaluation of an article's fact/opinionness as the covariate show similar though weaker results. Opinion is significantly related to perception of the referent in models with either environment $(F(1,53)=4.1 ; p<.05)$ or by by-line $(F(1,53)=3.8 ; p<.08)$. Consistent with the earlier surprising finding, opinion articles are more influential (lead to lower evaluations of the referent) than are articles perceived as fact $(r=.14 ; p<.001)$. Again, environment and by-line are clearly not significant when controlling for opinionness of the article (all $p>.2$ ).

\section{Discussion}

The rationale for protecting opinion is thoroughly integrated into the American legal fabric. One year after the ratification of the First Amendment, Thomas Jefferson wrote to George Washington, "If there be any among us who would wish to dissolve this union or to change its republican form, let them stand undisturbed as monuments of the safety with which error of opinion may be tolerated, where reason is left free to combat it." ${ }^{33}$ The plethora of opinion-wrongheaded, controversial, seditious, or otherwisethat makes up the free marketplace of ideas ${ }^{34}$ has long been recognized as a linchpin of democratic ideals.

Libel law attempts to incorporate the ideals of the open marketplace of ideas theory Jefferson so eloquently penned to Washington. Justice William Brennan's Opinion for the Court in New York Times v. Sullivan placed constitutional force behind the notion that even false defamatory statements of fact must be tolerated when they are directed at the public actions of public officials and they occur without actual malice. ${ }^{35}$ The marketplace, Brennan reasoned, requires "breathing space" if it is to flourish. ${ }^{36}$ Justice William Powell's opinion in Gertz v. Welch expanded the First Amendment foundation protecting criticism and required all courts to distinguish between statements of fact and statements of opinion.

This research focused not on the legal theory underlying the fact/opinion distinction in libel, but on assumptions about the manner in which people read newspapers-assumptions that can be found within the judicial process. We examined the judicial assumption in Oilman v. Evans that the macroenvironment in which statements appear is an important reader cue. We examined the related possibility that byline is an important indicator. We also examined the idea that people react differently to opinion statements than to factual statements in terms of reputation.

Our experimental findings strongly suggest that the macro-context does indeed matter. Placing the same article on the op/ed page and on the front page, readers were far more likely to perceived the article as opinion when it appeared on the op/ed page. Judge Starr's fourth criteria in Oilman finds support here as a means to distinguish between perceived statements of fact and opinion.

Each of the court's assumptions about page environment that we stated earlier appears borne out by the research. In drawing fact/ opinion distinctions readers appear to be aware at some level that they are reading statements placed either on a news page or on an op/ed page, and that there is a difference in function and content based on placement. Furthermore, these recognitions play a significant role in influencing reader perceptions of whether statements are fact or opinion.

Additional questions about the macro context are ripe for inquiry. Do readers relate differently to columns, editorials, and letters to the editor-the standard fare of the op/ed pages? Docs labeling such as 
"news analysis" make a difference in reader perception? Do people react differently to recognized bylines (columnist Ellen Goodman's, for example)?

Our readers did not appear to consider by-line in their determination of whether statements were fact or opinion. These results seemingly contradict the expectations suggested by earlier survey research. It is possible that our experimental subjects did not attend to the presence or absence of bylines as cues, while the survey respondents were asked directly about the significance of bylines as cues, artificially bringing the matter to their attention.

Material for a different debate emerges when we focus on the question of whether subjects were more influenced by statements of fact or statements of opinion. In our study, articles perceived as opinion appeared to influence readers more than articles perceived as factual. This is actually in line with earlier research that found tendency to see negative information as biased and opinionated, regardless of its factual basis. ${ }^{37}$ More negative articles, then, would be expected to produce greater opinion change, and would also be seen as more opinionated.

But while our findings suggest that opinion has the potential to cause equal or greater harm to reputation than does the publication of defamatory facts, our experimental environment in no way replicated the multitude of voices normally available to citizens. Legal commentator Robert Sack has noted that under constitutional law there can be no such thing as a false idea or opinion. As Sack wrote, "A defamation is actionable only if it is false; opinions cannot be false; therefore opinions can never be actionable even if defamatory." ${ }^{38}$ It may be, as the court implies in Gertz, that opinions cannot be proven true or false. Yet our research also suggests that opinions may be quite capable of carrying a defamatory reputational sting at least as damaging as any factual statement.

\section{Note:}

Jeremy Cohen and Clifford Nass are faculty members in the Department of Communication at Stanford where Laurie Mason is a doctoral student. Diana Mutz is a faculty member in the School of Journalism and Mass Communication at Wisconsin-Madison. This research was supported by a gift from the William Randolph Hearst Foundation to the first author.

${ }^{1}$ While truth is considered a "complete defense" to defamation under American common law, Robert Sack points out that "By statute or case law in a substantial minority of jurisdictions...truth is a defense only if the communication is published with good motives and for justifiable ends." Libel, Slander, and Related Problems. (New York: Practicing Law Institute, 1980). Pp. 130-131

${ }^{2}$ This is the area of libel that makes such distinctions as whether the plaintiff is a public official, a public figure or a private figure. Under certain circumstances the court may also consider whether the message is considered to be of public importance. See generally, Don Pember. Mass Media Law, $4^{\text {th }}$ ed, (Dubuque, lowa: Wm. C. Brown, Publishers, 1987).

${ }^{3}$ See generally, Timothy Gleason, "The Fact/Opinion Distinction in Libel Law." 10 Comm/Ent L Jour. Spring, 1988. 
${ }^{4}$ Gersz v. Robert Welch, Inc. 418 U.S. 323 (1974), 339-40, citing Thomas Jefferson's first Inaugural Address.

${ }^{5}$ Aldoupolis v. Globe Newspapers 500 N.E. 2d. 794 (Mass. 1986) at 798.

${ }^{6} / d .797$

${ }^{7}$ Ollman v. Evans. 750 F.2d 970 (1984), at 979.

${ }^{8} / d .981$.

${ }^{9} / d .989$.

${ }^{10} / d .983$.

${ }^{11} / d .990$.

${ }^{12} / d .1034$

${ }^{13}$ Timothy Gleasan. op. cit

${ }^{14}$ Newspaper Credibility Building Reader Trust, study conducted by MORI Research, Inc. Minneapolis, Minnesota for the American Society of Newspaper Editors, April 1985.

${ }^{15} \mathrm{An}$ additional assumption, that all statements are objectively fact or opinion, is a question of philosophy and is therefore beyond the scope of this paper.

${ }^{16}$ Pember, op. cit. p. 110.

${ }^{17}$ See generally, Lois G. Forer. A Chilling Effect (New York; Norton, 1987); Richard Labunski, Libel and the First Amendment (New Brunswick, N.J.: Transaction Press, 1987); Rodney Smolla, Suing the Press (New York: Oxford Press, 1986).

${ }^{18}$ See generally: Jeremy Cohen and Albert Gunther, "Libel as Communication Phenomena," 9 Communications and the Law Oct. 5, 1987, pp. 9-30; Jeremy Cohen, "Degrees of Freedom. Parameters of Communication Law Research," 8 Communications and the Law Aug. 4, 1986. Pp. 11-22; and William Haskins, John Patzke and Michael Price, "Freedom of Speech: A Review Based Upon Analytical Communication Models." 8 Communications and the Law June 3, 1986, pp. 37-54.

${ }^{19} 418$ U.S. 323 (1974) 339-40.

20750 F 2d 970 (1984).

${ }^{21}$ Mr. Chow v. Ste. Azur, 759 F.2d. 219 (2 ${ }^{\text {nd }}$ Cir. 1985); Janklow v. Newsweek, 788 F.2d. 1300 ( $8^{\text {th }}$ Cir. 1986); McCabe v. Rattiner, 814 F.2d 839 ( $1^{\text {st }}$ Cir. 1987); Keller v. Miami Herald, 788 F.2d $711\left(11^{\text {th }}\right.$ Cir. 1985).

${ }^{22}$ MORI research, op. cit., p. 34.

${ }^{23}$ Id. 32.

${ }^{24} / d$.

${ }^{25}$ Id. 33. 
${ }^{26}$ Journalists and Readers: Bridging the Credibility Gap. Associated Press Managing Editors Credibility Committee Report, 1985. p. 22.

${ }^{27}$ MORI Research op. cit., p.

${ }^{28}$ None of the students had been exposed to the legal debate concerning the fact/opinion distinction in law.

${ }^{29}$ The articles were: 1 ) a Chicago Tribune news story that generated Trump v. Chicago Tribune Co., (DS SNY, 1985) 616 F. Supp. 1434; 2) a Newsweek news story that generated Kaplan v. Newsweek, (CA 9, 1985) unpub., 776 F.2d 1053 (the prior decision can be found under Kaplan v. Newsweek (DC NCal, 1984)); 3) a Cleveland Plain Dealer news story that generated Dental Care Clinic v. McDonough, (Ohio Ct. App. 1986); and 4) an Evans and Novak nationally-syndicated op-ed piece that generated Ollman v. Evans, 750 F.2d 970 (1984). In each case, fictitious names were used in our articles. All articles were edited for length.

${ }^{30}$ Extensive de-briefing of the subjects indicated that no subjects thought that the pages selected from the newspaper or any of the articles were fictitious.

${ }^{31}$ In determining the significance of the main effects and the interaction in a Latin-square design, one calculates the $F$ statistic by dividing the mean square associated with the effect by the mean square associated with the effect-by-subject-within-form.

${ }^{32}$ Due to limitations of computer memory, we could not use environment and by-line simultaneously as independent effects.

${ }^{33}$ Inaugural Address cited in Jeffery Smith, Printers and Press Freedom. The Ideology of Early American Journalism. New York: Oxford Press, 1988, p. 40.

${ }^{34}$ The marketplace of ideas concept is discussed at length is Smith's treatise. Justice Holmes first introduced it as a First Amendment consideration in his dissent in Abrams v. United States, 250 U.S. 616 (1919).

35376 U.S. 254 (1964).

${ }^{36}$ Ibid.

${ }^{37}$ See Jeremy Cohen, Diana Mutz, Vincent Price and Albert Gunther. Perceived Impact of Defamation. Public Opinion Quarterly. 52:163-73 (summer 1988).

${ }^{38}$ Sack, p.154 